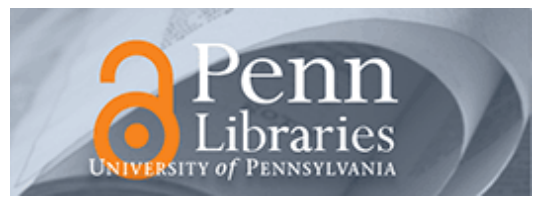

University of Pennsylvania ScholarlyCommons

$9-1-2001$

\title{
Teacher Turnover and Teacher Shortages: An Organizational Analysis
}

Richard Ingersoll

University of Pennsylvania, rmi@upenn.edu

Follow this and additional works at: https://repository.upenn.edu/gse_pubs

Part of the Other Education Commons

\section{Recommended Citation}

Ingersoll, R. (2001). Teacher Turnover and Teacher Shortages: An Organizational Analysis. Retrieved from https://repository.upenn.edu/gse_pubs/94

Reprinted from American Educational Research Journal, Fall 2001, Volume 38, Issue 3, pages 499-534. Publisher URL: http://hdl.library.upenn.edu/1017/13673

NOTE: The author, Dr. Richard M. Ingersoll, asserts his right to include this material in ScholarlyCommons@Penn.

This paper is posted at ScholarlyCommons. https://repository.upenn.edu/gse_pubs/94

For more information, please contact repository@pobox.upenn.edu. 


\title{
Teacher Turnover and Teacher Shortages: An Organizational Analysis
}

\begin{abstract}
Contemporary educational theory holds that one of the pivotal causes of inadequate school performance is the inability of schools to adequately staff classrooms with qualified teachers. This theory also holds that these school staffing problems are primarily due to shortages of teachers, which, in turn, are primarily due to recent increases in teacher retirements and student enrollments. This analysis investigates the possibility that there are other factors - those tied to the organizational characteristics and conditions of schools - that are driving teacher turnover and, in turn, school staffing problems. The data utilized in this investigation are from the Schools and Staffing Survey and its supplement, the Teacher Followup Survey conducted by the National Center for Education Statistics. The results of the analysis indicate that school staffing problems are not primarily due to teacher shortages, in the technical sense of an insufficient supply of qualified teachers. Rather, the data indicate that school staffing problems are primarily due to excess demand resulting from a "revolving door" - where large numbers of qualified teachers depart their jobs for reasons other than retirement. Moreover, the data show that the amount of turnover accounted for by retirement is relatively minor when compared to that associated with other factors, such as teacher job dissatisfaction and teachers pursuing other jobs. The article concludes that popular education initiatives, such as teacher recruitment programs, will not solve the staffing problems of such schools if they do not also address the organizational sources of low teacher retention.
\end{abstract}

\section{Disciplines}

Other Education

\section{Comments}

Reprinted from American Educational Research Journal, Fall 2001, Volume 38, Issue 3, pages 499-534. Publisher URL: http://hdl.library.upenn.edu/1017/13673

NOTE: The author, Dr. Richard M. Ingersoll, asserts his right to include this material in ScholarlyCommons@Penn. 
American Educational Research Journal

Fall 2001, Vol. 38, No. 3, pp. 499-534

\title{
Teacher Turnover and Teacher Shortages: An Organizational Analysis
}

\author{
Richard M. Ingersoll \\ University of Pennsylvania
}

Contemporary educational theory holds that one of the pivotal causes of inadequate school performance is the inability of schools to adequately staff classrooms with qualified teachers. This theory also holds that these school staffing problems are primarily due to shortages of teachers, which, in turn, are primarily due to recent increases in teacher retirements and student enrollments. This analysis investigates the possibility that there are other factors - those tied to the organizational characteristics and conditions of schools - that are driving teacher turnover and, in turn, school staffing problems. The data utilized in this investigation are from the Schools and Staffing Survey and its supplement, the Teacher Followup Survey conducted by the National Center for Education Statistics. The results of the analysis indicate that school staffing problems are not primarily due to teacher shortages, in the technical sense of an insufficient supply of qualified teachers. Rather, the data indicate that school staffing problems are primarily due to excess demand resulting from a "revolving door"-where large numbers of qualified teachers depart their jobs for reasons other than retirement. Moreover, the data show that the amount of turnover accounted for by retirement is relatively minor when compared to that associated with other factors, such as teacher job dissatisfaction and teachers pursuing other jobs. The article concludes that popular education initiatives, such as teacher recruitment programs, will not solve the staffing problems of such schools if they do not also address the organizational sources of low teacher retention.

Richard M. IngERsoll is Associate Professor, Graduate School of Education, University of Pennsylvania, 3440 Market Street, Philadelphia, PA 19104. His specializations are the sociology of organizations, occupations, and work and the sociology of education. E-mail: rmi@gse.upenn.edu 
Ingersoll

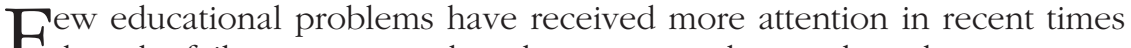
Than the failure to ensure that elementary and secondary classrooms are all staffed with qualified teachers. In the early 1980s, a series of highly publicized reports began to focus national attention on the coming possibility of severe teacher shortages in elementary and secondary schools (e.g., Darling-Hammond, 1984; National Commission on Excellence in Education, 1983; for reviews of this debate, see Boe \& Gilford, 1992; Haggstrom, Darling-Hammond, \& Grissmer, 1988; National Academy of Sciences, 1987). These studies predicted a dramatic increase in the demand for new teachers primarily resulting from two converging demographic trends-increasing student enrollments and increasing teacher attrition due to a "graying" teaching force. These reports held that subsequent shortfalls of teachers would, in turn, force many school systems to resort to lowering standards to fill teaching openings, inevitably resulting in high levels of under-qualified teachers and lower school performance. The inability of schools to adequately staff classrooms with qualified teachers (hereafter referred to as school staffing problems) has since been cast as a major educational problem, received widespread coverage in the national media, been the target of a growing number of reform and policy initiatives, and been the subject of a substantial body of empirical research (for a review of this issue, see National Commission on Teaching and America's Future, 1997).

The dominant policy response to school staffing problems has been to attempt to increase the supply of available teachers through a wide range of recruitment initiatives. Some programs, such as "troops-to-teachers," are designed to entice professionals into mid-career changes to teaching. Others, such as "Teach for America" seek to lure the "best and brightest" into teaching. A wide range of alternative licensing programs are designed to ease entry into teaching. Finally, financial incentives, such as signing bonuses, student loan forgiveness, housing assistance, and tuition reimbursement have all been instituted to aid recruitment (Clinton, 1999; Feistritzer, 1997; Kopp, 1992; Hirsch, Koppich, \& Knapp, 2001).

Concern over shortages has also provided the impetus for empirical research on teacher supply and demand. In particular, over the past two decades a substantial body of empirical analysis has focused on teacher turnover - the departure of teachers from their teaching jobs (e.g., Grissmer \& Kirby, 1987, 1992, 1997; Heyns, 1988; Murnane, 1981, 1987; Murnane, Singer, \& Willett, 1988). This article also examines teacher turnover, but from a different perspective than most previous empirical studies on this topic. Existing research has generally sought to explain teacher turnover as a function of the characteristics of individual teachers. Moreover, most research has focused on narrow subsets of the total turnover and interorganizational mobility of teachers. This analysis attempts to extend existing theory and research by examining teacher turnover from an organizational perspective. The theoretical perspective of this analysis, drawn from the sociology of organizations, occupations, and work, holds that teacher turnover and, in turn, school staffing problems cannot be fully understood without closely 
examining the characteristics of the organizations that employ teachers and also examining turnover at the level of the organization.

In brief, the results of the analysis show that teacher turnover is a significant phenomenon, and a dominant factor behind the demand for new teachers and the difficulties schools encounter adequately staffing classrooms with qualified teachers. Consistent with prior empirical research, my analysis indicates that teacher characteristics, such as specialty field and age, are strongly related to turnover. But, net of the effects of these teacher characteristics, there are also significant effects of school characteristics and organizational conditions on turnover that have largely been overlooked by previous research. The data show, for example, that although high-poverty public schools have moderately higher rates, larger schools, public schools in large school districts, and urban public schools do not have especially high rates of teacher turnover. In contrast, small private schools stand out for their relatively high rates of turnover. Moreover, the data show that although it is true that teacher retirements are increasing, the overall amount of turnover accounted for by retirement is relatively minor when compared to that associated with other factors, such as teacher job dissatisfaction and teachers pursuing better jobs or other careers. The data show that, in particular, inadequate support from the school administration, student discipline problems, limited faculty input into school decision-making, and to a lesser extent, low salaries, are all associated with higher rates of turnover, after controlling for the characteristics of both teachers and schools.

These findings have important implications for both theory and policy concerning school staffing problems. As mentioned, existing theory holds that teacher shortages, largely due to inexorable, macro, demographic trends, are the primary factor behind staffing problems. In turn, the dominant policy response has been to attempt to increase the quantity of teachers supplied through various recruitment strategies. In contrast, this analysis suggests that the imbalance of teacher supply and demand at the root of school staffing problems is neither synonymous with, nor primarily due to, teacher shortages in the technical sense of a deficit in the quantity of qualified candidates. Rather than insufficient supply, the data indicate that school staffing problems are primarily due to excess demand, resulting from a "revolving door"-where large numbers of teachers depart their jobs for reasons other than retirement. Thus, the data suggest that the solution to staffing problems does not primarily lie in increasing supply, but rather in decreasing demand. In plain terms, teacher recruitment programs alone will not solve the staffing problems of schools if they do not also address the organizational sources of low retention.

This analysis also has implications for the literature on school community and school effectiveness. Educational sociologists, in particular, have long held that the presence of a sense of community and cohesion among families, teachers, and students is important for the success of schools (e.g., Durkheim, 1961; Waller, 1932; Parsons, 1959; Grant, 1988; Rosenholtz, 1989). In general, large urban, high-poverty public schools are often cited as 


\section{Ingersoll}

those least likely to be characterized by a tight-knit sense of cohesion, whereas small private schools are often cited as those most likely to be so characterized (e.g., Bryk, Lee, \& Smith, 1990; Coleman \& Hoffer, 1987). This analysis reveals that the latter have far higher rates of teacher turnover than the former. The article closes by offering a hypothesis to account for these counterintuitive findings.

Below, I first review in more detail the existing empirical research on teacher turnover and what I believe are its limitations.

\section{Research on Teacher Turnover}

During the last two decades, substantial empirical research has focused on determining which kinds of teachers are more prone to leave teaching and why (e.g., Bobbitt, Leich, Whitener, \& Lynch, 1994; Chapman \& Green, 1986; Chapman \& Hutcheson, 1982; Grissmer \& Kirby, 1987, 1992, 1997; Hafner \& Owings, 1991; Haggstrom, Darling-Hammond, \& Grissmer, 1988; Heyns, 1988; Marso \& Pigge, 1991; Miech \& Elder, 1996; Murnane, 1981, 1987; Murnane, Singer, Willet, Kemple, \& Olsen, 1991; Murnane, Singer, \& Willett, 1988; Rumberger, 1987; Schlechty \& Vance, 1981, 1983; Weiss \& Boyd, 1990). This research shows that teacher turnover is strongly correlated with the individual characteristics of teachers. Among the most important findings has been that teacher turnover is related to the teaching field. Although the data have been inconsistent at times, special education, mathematics, and science are typically found to be the fields of highest turnover (Boe, Bobbitt, \& Cook, 1997; Grissmer \& Kirby, 1992; Murnane et al., 1991; Rumberger, 1987).

Another important finding has been that teachers' decisions whether to stay or leave the teaching profession are related to their age. The relationship between teachers' age (or teaching experience, in some analyses) and their turnover follows a U-shaped curve. Although there is some disagreement as to why this is the case, researchers have consistently found that younger teachers have very high rates of departure. Subsequently, as those remaining "settle in," turnover rates decline through the mid-career period and, finally, rise again in the retirement years (e.g., Bobbitt, Leich, Whitener, \& Lynch, 1994; Boe, Bobbitt, Cook, Barkanic, \& Mailsin, 1998; Grissmer \& Kirby, 1987, 1992, 1997; Hafner \& Owings, 1991; Murnane, Singer, \& Willett, 1988). Moreover, because the distribution of age in the teaching force is skewed upward-older teachers significantly outnumber younger teachers-many analysts have concluded that retirement due to a rapidly "graying" teaching workforce is the most significant factor behind teacher turnover, teacher shortages, and school staffing problems (e.g., Grissmer \& Kirby, 1997).

Such research has provided a great deal of insight into some of the sources of teacher turnover; however, there are two important limitations to existing empirical studies. First, most of this empirical research has sought to explain teacher turnover as a function of the characteristics of individual teachers. Researchers have rarely focused on explaining teacher turnover as 
Teacher Turnover and Teacher Shortages

a function of schools. To be sure, a number of analysts have compared or controlled for turnover differences across different types of schools (e.g., Bacharach \& Bamberger, 1990; Bobbitt, Leich, Whitener, \& Lynch, 1994; Boe, Bobbitt, Cook, Barkanic, \& Mailsin, 1998; Heyns, 1988; Miech \& Elder, 1996; Murnane, 1981; Sclan, 1993; Theobald, 1990). However, few have examined in detail which characteristics and conditions of schools are related to teacher turnover, especially with large-scale or representative data. ${ }^{1}$ Although it is widely believed, for example, that urban, high-poverty public schools have very high levels of teacher turnover (e.g., Darling-Hammond \& Green, 1994; Kozol, 1991; Oakes, 1990; Rosenholtz, 1985), there have been few attempts to rigorously test this assumption with nationally representative data or to examine which aspects of these schools contribute to teacher turnover.

In addition, much of the empirical research has tended to emphasize only one component of the overall flow of teachers from schools-those who leave the occupation of teaching altogether, often (and hereafter) referred to as teacher attrition. Researchers have often de-emphasized the other major component of turnover-those who transfer or move to different teaching jobs in other schools, often (and hereafter) referred to as teacher migration. To be sure, a number of analysts have examined levels and variations in cross-school teacher migration (e.g., Boe, Bobbitt, Cook, Barkanic, \& Mailsin, 1998; Grissmer \& Kirby, 1987, 1992; Murnane, 1981; Rollefson \& Broughman, 1995). However, many assume migration is a less significant form of turnover because it does not increase or decrease the overall supply of teachers, as do retirements and career changes, and thus, does not contribute to overall systemic shortages.

These are important limitations. As a result of an emphasis on individual-level factors, much less is known about whether teacher turnover is disproportionately concentrated in particular types of schools. Moreover, little is known of how the organizational conditions of schools both impact and are impacted by turnover. In addition, about half of the overall turnover of teachers is migration from one school to another (Ingersoll 1995a, pp. 4-9) and, hence, an emphasis on attrition has meant that much less is known about the magnitude and causes of the totality of employment instability, turnover, and interorganizational mobility in schools. Perhaps because of these limits, much of this empirical literature treats the study of teacher turnover as an isolated topic and does not explicitly connect turnover to the larger issues of shortages, staffing problems, and their implications for school performance (e.g., Chapman \& Green, 1986; Chapman \& Hutcheson, 1982; Hafner \& Owings, 1991; Marso \& Pigge, 1991).

One reason for these research limitations has been a lack of data (especially at a nationally representative level) on the extent of, types of, and reasons for teacher turnover. For example, some of the best-known research on teacher attrition used single-city or single-state data (e.g., Grissmer \& Kirby, 1992; Murnane, 1981; Murnane et al., 1991; Schlechty \& Vance, 1981, 1983). In addition to obvious limits to generalization, another key limitation 
Ingersoll

of such data is that it is difficult to distinguish between teacher attrition and teacher migration to teaching jobs in other cities or states because the latter "leave" the sampling frame.

It was partly in order to address these data shortcomings that the U.S. Department of Education's National Center for Education Statistics (NCES) conducted the Schools and Staffing Survey (SASS) and its supplement, the Teacher Followup Survey (TFS), beginning in the late 1980s. Unlike most previous data sources, this dataset is large, comprehensive, nationally representative, and includes teacher migration, teacher attrition, the reasons teachers themselves give for their departures, and a wide range of information on the characteristics and conditions of elementary and secondary schools.

\section{Teacher Turnover and Teacher Shortages: An Organizational Analysis}

The objective of this study is to use the SASS/TFS data to examine teacher turnover and school staffing problems from an organizational perspective. Employee supply, demand, and turnover are central issues in organizational theory and research. Likewise, school staffing problems and teacher turnover are central issues in educational research and policy. However, there have been few efforts to apply the former perspective to the latter issues.

My analysis is based upon three general inter-related premises, drawn from the sociology of organizations, occupations, and work and the empirical literature on employee turnover: (a) understanding employee turnover is important because of its link to the performance and effectiveness of organizations; (b) fully understanding turnover requires examining it at the level of the organization; and (c) fully understanding turnover requires examining the character and conditions of the organizations within which employees work. Although these premises are commonplace to the literature on employee turnover, they are not so in the literature on teacher turnover and warrant brief explanation here.

Research on employee turnover is extensive and has examined a wide variety of aspects of employee stability, turnover, and mobility, with, at times, inconsistent findings (e.g., Price 1977, 1989; Mueller \& Price, 1990; Bluedorn, 1982; Halaby \& Weakliem, 1989; Hom \& Griffeth, 1995; Kalleberg \& Mastekaasa, 1998; March \& Simon, 1958; Mobley, 1982; Steers \& Momday, 1981). ${ }^{2}$ However, consistently running throughout virtually all of this literature is the premise that employee turnover is important because of its link to the performance and effectiveness of organizations. On the one hand, researchers have found that a low level of employee turnover is normal and efficacious in a well-managed organization. Too little turnover of employees is tied to stagnancy in organizations; effective organizations usually both promote and benefit from a limited degree of turnover by eliminating lowcaliber performers and bringing in "new blood" to facilitate innovation. On 
the other hand, a central finding in this literature is that high levels of employee turnover are both cause and effect of ineffectiveness and low performance in organizations.

Organizational analysts have also noted that the organizational consequences of employee turnover vary among different types of employees and among different types of organizations. Labor process analysts, for instance, have argued that a major issue, from the viewpoint of organizational management, is the extent to which the organization is or is not dependent on particular types of employees and, hence, vulnerable to the disruption caused by their turnover (e.g., Braverman, 1974; Burawoy, 1979; Edwards, 1979). For just this reason the issue of employee "substitutability," or the ease with which organizations can replace employees, is a central concern in organizational management and a central theme in organizational research. In this perspective, employee turnover is especially consequential in organizations that have uncertain and nonroutine technologies and production processes requiring extensive interaction among participants. Such organizations are often unusually dependent upon commitment and cohesion among employees and management and, hence, are especially vulnerable to employee turnover (e.g., Burns \& Stalker, 1961; Kanter, 1977; Likert, 1967; Porter, Lawler \& Hackman, 1975; Turner \& Lawrence, 1964; Walton, 1980).

Schools have traditionally been identified as a key example of organizations characterized by an uncertain and nonroutine technology and by dependence on commitment and cohesion among members (Bidwell, 1965; Ingersoll, 1993; Lortie, 1975). Indeed, the presence of a positive sense of community among families, teachers, and students has long been held by education researchers to be one of the most important indicators and aspects of successful schools (e.g., Durkheim, 1961; Waller, 1932; Parsons, 1959; Grant, 1988; Coleman \& Hoffer, 1987; Kirst, 1989; Rosenholtz, 1989). Hence, from an organizational perspective, high turnover of teachers from schools is of concern not simply because it may be an indicator of sites of potential staffing problems, but because of its relationship to school cohesion and, in turn, performance. Moreover, from this perspective this relationship runs both directions. That is, high rates of teacher turnover are of concern not only because they may be an outcome indicating underlying problems in how well schools function, but also because they can be disruptive, in and of themselves, for the quality of school community and performance.

Also important to my analysis is a second and related premise that fully understanding turnover requires examining it at the level of the organization. The level of analysis is especially important for deciding which types of employee flows out of organizations are considered relevant. As discussed above, research on teacher turnover places much emphasis on the distinction between those leaving the occupation altogether and those moving to teaching jobs in other schools. The latter is often assumed to be irrelevant from a systemic-level perspective. In contrast, this distinction is rarely noted in the literature on employee turnover. From an organizational-level perspective, employee migration is as relevant as employee attrition. The prem- 
Ingersoll

Table 1

Two Perspectives on the Causes and Consequences of School Staffing Problems

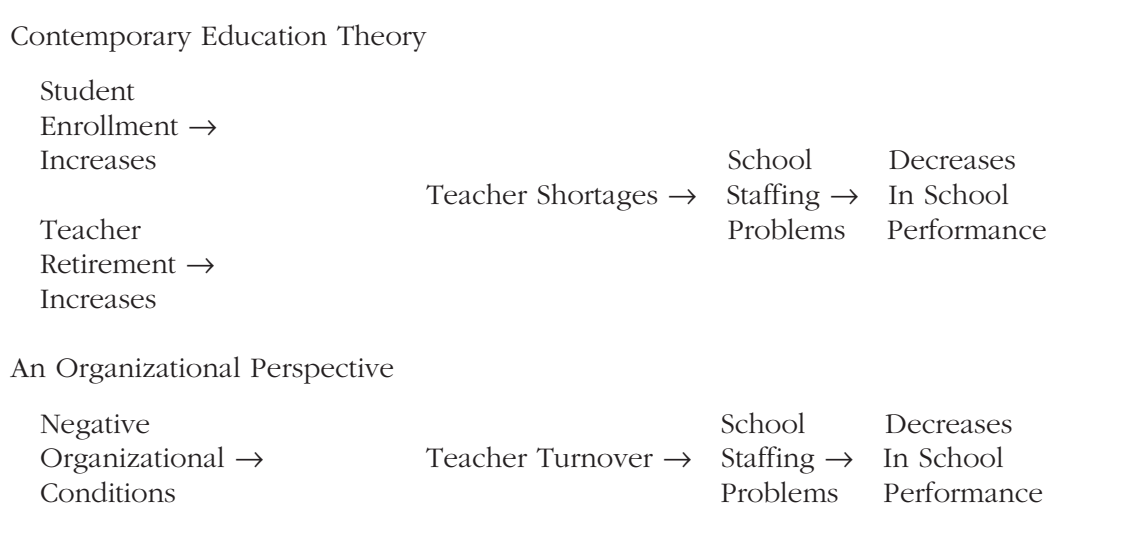

ise underlying this perspective is that, whether those departing are moving to a similar job in another organization or leaving the occupation altogether, their departures similarly impact and are impacted by the organization.

The third premise underlying this analysis is that fully understanding turnover requires examining the character and conditions of the organizations within which employees work. A long tradition of research has shown that, in addition to individual and personal characteristics of employees, the overall conditions of workplaces and job sites significantly affect the attachment of employees to the organization (e.g., Price 1977, 1989; Mueller \& Price, 1990; Bluedorn, 1982; Halaby \& Weakliem, 1989; Hom \& Griffeth, 1995; Kalleberg \& Mastekaasa, 1998; March \& Simon, 1958; Mobley, 1982; Steers \& Momday, 1981). Researchers have found that among the most important of these organizational conditions are the compensation structure for employees; the level of administrative support, especially for new employees; the degree of conflict and strife within the organization; and the degree of employee input into and influence over organization policies. This research has found strong links between these kinds of organizational conditions and employee motivation, commitment, and turnover. From this perspective, it is reasonable to expect that these same organizational conditions may also be among the more important factors affecting the rates at which teachers depart particular schools.

This study is drawn from a larger project that examines issues of teacher supply, demand, and quality from an organizational perspective. ${ }^{3}$ In this article, I focus on teacher turnover and compare and contrast an organizational perspective with the dominant contemporary educational perspective on the source of school staffing problems (see Table 1). My analysis has two specific objectives. The first is to investigate the role of teacher turnover in the staffing problems of schools. I examine the overall magnitude of both 
teacher attrition and migration, compare the rates of teacher turnover with those of other occupations, and ascertain the portion of the demand for new teachers that is accounted for by turnover. The second objective is to examine the role of school characteristics and organizational conditions in teacher turnover. I examine whether there are significant differences in levels of teacher turnover at different types of schools and whether the organizational conditions in schools are related to teacher turnover, after controlling for the characteristics of teachers and schools. This study does not attempt to provide a comprehensive analysis of all the many aspects of the organization of schools that may possibly impact the turnover of teachers. In previous analyses I have examined the effects of a wide variety of workplace characteristics on teacher turnover (see, e.g., Ingersoll, 1995a, 2001b). In this analysis, I focus on a set of four particular organizational conditions in schools that, as discussed above, have consistently been found to be crucial for employee turnover: the compensation structure for employees; the level of administrative support, especially for new employees; the degree of conflict and strife within the organization; and the degree of employee input into and influence over organization policies. These four conditions are a useful focus because they have also been found to be among the most important aspects of school organization and are "policy amenable" (see, e.g., Goodlad, 1984; Metz, 1986; Newman, Rutter, \& Smith, 1989; Pallas, 1988; Rosenholtz, 1989; Grant, 1988). This analysis examines the strength and consistency of their association with teacher turnover, across a range of schools and across different subsets of turnover.

\section{Data and Methods}

\section{Data}

As indicated, the data for this study come from the NCES nationally representative SASS and its supplement, the TFS. This is the largest and most comprehensive data source available on the staffing, occupational, and organizational aspects of elementary and secondary schools, and was specifically designed to remedy the lack of nationally representative data on these issues (Haggstrom, Darling-Hammond, \& Grissmer, 1988; Ingersoll, 1995b).

The U.S. Census Bureau (1998) collected the SASS data for NCES from a random sample of schools stratified by state, public/private sector, and school level. There are three SASS cycles to date: 1987-1988, 1990-1991, and 1993-1994. Each cycle of SASS included separate, but linked, questionnaires for administrators and for a random sample of teachers in each school. In addition, after 12 months, the same schools were again contacted and all those in the original teacher sample who had moved from or left their teaching jobs were given a second questionnaire to obtain information on their departures. This latter group, along with a representative sample of those who stayed in their teaching jobs, comprises the TFS. This analysis primarily uses data from the 1991-1992 TFS, linked with data from the 1990-1991 SASS teacher and administrator questionnaires. 


\section{Ingersoll}

The 1991-1992 TFS sample comprises 6,733 elementary and secondary teachers (3,343 continuing teachers, 1,428 migrations, and 1,962 attritions). This analysis uses data weighted to compensate for the over- and undersampling of the complex stratified survey design. Each observation is weighted by the inverse of its probability of selection in order to obtain unbiased estimates of the national population of schools and teachers in the year of the survey. ${ }^{4}$

\section{Methods}

This investigation is unusual in that it does not solely focus on a particular subset of turnover and interorganizational mobility. Unlike most research on teacher turnover, this analysis examines all turnover or departures, including both teacher migration and teacher attrition, which I will refer to as movers and leavers, respectively. Moreover, unlike most research on employee turnover, this analysis examines both voluntary and involuntary turnover (the latter typically includes retirements, layoffs, terminations). ${ }^{5}$ This study assesses these different types of flows both together, to capture the totality, and separately, to examine differences. ${ }^{6}$

The analysis is divided into three stages. In the first stage I establish the overall magnitude of annual teacher turnover and its role in teacher demand and school staffing problems. In the second stage I conduct a multiple regression analysis of the effects of teacher characteristics, school characteristics, and organizational conditions on turnover. In the third stage I follow up with a detailed examination of the reasons teachers themselves give for their departures. These three stages of my analysis are described in more detail below.

I first summarize descriptive data on recent trends in the overall magnitude of annual teacher migration, attrition, and retirement; their impact on the demand for new teachers; and their role in the difficulties schools encounter adequately staffing classrooms with qualified teachers. I also establish the extent of variation in turnover across different types of schools and compare these levels to employee turnover in other occupations.

The second stage presents a multiple regression analysis of the predictors of teacher turnover. The dependent variable-teacher turnover-is a dichotomous variable based on whether each teacher remained with or departed from his or her teaching job in the year of the survey. I cumulatively examine three groups of predictors of turnover: teacher characteristics, school characteristics, and organizational conditions. Table 2 provides definitions for these variables. Table 3 provides mean teacher and school characteristics associated with the teachers in the sample.

Following previous research on teacher turnover, in the regression models I include control variables for several characteristics of teachers: race, gender, age, and subject/field of teaching. Because of its U-shaped relationship, I transform age into a three-category set of dummy variables-younger (less than 30 years), middle-aged (31-50 years) and older (greater than 50 years). 
Teacher Turnover and Teacher Shortages

Following previous research on school organization (e.g., Bidwell \& Quiroz, 1991; Bryk, Lee, \& Smith, 1990; Chubb \& Moe, 1990; Coleman \& Hoffer, 1987; Pallas, 1988; Rowan, Raudenbush, \& Kang 1991), in the regression models I include, as independent variables, school characteristics typically found to be important in this literature: school level, size, urbanicity, sector, the level of poverty of the student population, and the orientation or affiliation for private schools (Catholic, other religious, and nonsectarian).

Finally, and only after controlling for the above teacher and school factors, I focus on the effects of four measures reflecting the four organizational conditions introduced earlier. Unlike most empirical analyses that use either individual teacher's salaries or the school's mean teacher salary, I use the normal yearly base salary for advanced teachers (those with an MA degree and at least 20 years experience) drawn from school salary schedules, because it better assesses differences in the organizational-level compensation structure. ${ }^{7}$ For administrative support I utilize an index of the degree of assistance provided to new teachers, as reported by all teachers. For the degree of conflict and strife within the organization I use an index of the level of student discipline problems within schools, as reported by teachers. For the degree of employee input into and influence over organization policies, I use an index of the degree of faculty classroom control and influence over school policies, as reported by teachers. In other analyses I have also tested a number of other related measures of organizational conditions, such as faculty collegiality/cohesion, faculty decision-making influence according to type of issue, student alienation, administrative support for all teachers and the provision of merit pay, mentoring programs, and support for professional development (see, e.g., Ingersoll, 1995a, 2001b). The effects of these were similar to the above four measures, but the relationships were weaker, and for reasons of parsimony were dropped from this analysis.

This second stage of the analysis examines whether the likelihood of individual teachers moving from or leaving their teaching jobs is related to the above-described school-level measures of school characteristics and organizational conditions, while controlling for individual-level characteristics of teachers. Multilevel regression is necessary in order to simultaneously account for variation in turnover, both between teachers within schools and between teaching staffs across schools. The analysis uses PROC GENMOD (SAS), a multilevel regression program that allows for logistic regression, adjusts for the nonrandom clustering of teachers within schools resulting from the multilevel sample, and finally, allows for the inclusion of design weights. Use of weights is necessary because the TFS sample is based on those who departed their teaching jobs and undersamples those who did not depart.

Following the regression analysis is a third stage involving a more indepth examination of the reasons teachers themselves give for their turnover. I analyze data drawn from an additional set of items in the TFS questionnaire that asked teacher-respondents to indicate the reasons (up to 
Table 2

\section{Definitions of Measures Used in the Analysis}

Teacher Turnover: a dichotomous variable where $1=$ not teaching in same school as last year and $0=$ stayer/currently teaching in same school.

Teacher Characteristics

Young: a dichotomous variable where $1=$ teacher less than 30 years of age and $0=$ other teachers.

Old: a dichotomous variable where $1=$ teacher older than 50 years of age and $0=$ other teachers.

Math/Science: a dichotomous variable where $1=$ teachers listed by their principals as primarily teaching secondary math or science and $0=$ all other teachers.

Special Education: a dichotomous variable where 1 = teachers listed by their principals as primarily teaching elementary or secondary special education and $0=$ other teachers.

Male: a dichotomous variable where $1=$ male teacher and $0=$ female teacher .

Minority: a dichotomous variable where $1=$ nonwhite teacher and $0=$ other teachers.

School Characteristics

Private: a dichotomous variable where $1=$ private and $0=$ public

Size: student enrollment of school.

Rural: a dichotomous variable where $1=$ rural and $0=$ suburban or urban

Suburban: a dichotomous variable where $1=$ suburban and $0=$ rural or urban

Secondary Level: a dichotomous variable where $1=$ junior or senior secondary and $0=$ elementary or middle or combined (K-12).

Public schools

District Size: student enrollment of school district.

Poverty Enrollment: percentage of students receiving the federal free or reduced-price lunch program for students from families below poverty level. Not available for private schools.

Private schools

Catholic: a dichotomous variable for school orientation where $1=$ Catholic and $0=$ other religious or nonsectarian

Other Religious: a dichotomous variable for school orientation where $1=$ other religious and $0=$ Catholic or nonsectarian

Organizational Conditions

Advanced Salary: normal yearly base salary for teacher with a MA and 20 years of experience, as reported by school administrators. This measure excludes private school teachers whose effort is contributed as a free service.

Administrative Support: on a scale of $1=$ strongly disagree to $4=$ strongly agree, the school mean of the amount of agreement of all teachers with the statement "this school is effective in assisting new teachers" for 4 related items: student discipline, instructional methods, curriculum, and adjusting to the school environment.

Student Discipline Problems: on a scale of $1=$ not a problem to $4=$ serious, the school mean of teachers' reports for 8 kinds of student discipline problems: Studistive behavior, absenteeism, physical conflicts among students, robbery, vandalism, weapon possession, physical abuse of teachers, verbal abuse of
disruptis teachers. 
Table 2 (Continued)

Faculty Influence: on a scale of $1=$ none to $6=a$ great deal, the school mean of faculty control and influence over 10 areas: selecting textbooks and other instructional materials; selecting content, topics and skills to be taught; selecting teaching techniques; determining the amount of homework to be

assigned; disciplining students; curriculum; ability grouping; school discipline policy; content of inservice programs.

Factor analysis (with varimax rotation method) was used to develop the indices of student discipline problems and faculty influence. Item loadings of .4 were considered necessary for inclusion in a factor. No items loaded on more than one factor. Each factor had high internal consistency $(\mathrm{a}>.7)$. The measures of student discipline problems, faculty influence and administrative support are all school means of the reports of the total SASS teacher sample for each school and not limited to the reports of those in the smaller TFS sample. Intercorrelations among the four conditions were moderate to low $(<.44)$

\section{Reasons for Turnover (Table 5)}

Teachers could list up to 3 choices from a list of 12 reasons for their departures. I grouped the 12 reasons into 5 categories, as follows

School Staffing Action: reduction-in-force/lay-off/school closing/reassignment.

Dissatisfaction: dissatisfied with teaching as a career; dissatisfied with the school; for better salary or benefits.

Personal: family or personal move; pregnancy/child rearing; health; other family or personal reason.

To Pursue Other Job: to pursue another career; to take courses to improve career opportunities in or outside the field of education; for better teaching job. Retirement.

Of those teachers who indicated dissatisfaction, as defined above, as a reason for their departure, they could list up to 3 choices from a list of 15 reasons for their dissatisfaction. From these reasons I drew 13 categories, as follows:

Inadequate Administrative Support: inadequate support from administration.

Poor Salary.

\section{Student Discipline Problems.}

Lack of Faculty Influence: lack of influence over school policies and practices; lack of control over own classroom.

Lack of Student Motivation: poor student motivation to learn.

Class Sizes Too Large

Inadequate Time to Prepare: inadequate time to prepare lesson/teaching plans.

Unsafe Environment: unsafe working environment.

Poor Opportunity for Professional Advancement.

Lack of Community Support: lack of community support for schools.

Interference in Teaching: interference from others regarding what I taught.

Lack of Professional Competence of Colleagues.

Intrusions on Teaching Time: (i.e. not enough time working directly with teaching students). 
Ingersoll

Table 3

Means and Standard Deviations for Variables Utilized in Regression Analysis

\begin{tabular}{lcc}
\hline & Mean & $S D$ \\
\hline Teacher characteristics & & - \\
Young & 0.11 & - \\
Old & 0.09 & - \\
Math/science & 0.11 & - \\
Special education & 0.10 & - \\
Male & 0.28 & - \\
Minority & 0.13 & - \\
School characteristics & & - \\
Private & 0.24 & - \\
Size & 684 & 0.40 \\
Rural & 0.31 & -26 \\
Suburban & 0.33 & - \\
Secondary level & 44,815 & \\
District size (public only) & 0.31 & 0.437 \\
\% Poverty enrollment (public only) & 0.43 & 0.47 \\
Catholic (private only) & 0.36 & 0.44 \\
Other religious (private only) & & 0.53 \\
Organizational conditions & 35,499 & \\
Advanced salary (\$) & 2.98 & \\
Administrative support & 1.84 & \\
Student conflict & 4.5 & \\
Faculty influence & & \\
& & \\
\hline
\end{tabular}

three) for their departures from a list in the survey questionnaire. For those who had indicated job dissatisfaction as a reason for their turnover, I also analyze data from a subsequent set of items that asked these respondents to indicate the sources (up to three) of their dissatisfaction (see Table 2). Selfreport data such as these are useful because those departing are, of course, often in the best position to know the reasons for their departures. But, such self-report data are also retrospective attributions, subject to bias and, hence, warrant caution in interpretation. Here I utilize the self-report data in conjunction with the prior regression analysis, which is based on school-level data from a larger set of respondents. This allows the analysis to both take advantage of the unusual breadth of the SASS/TFS data and also provides a means of comparing the two sets of findings concerning the relationship between school characteristics, organizational conditions, and turnover.

There is also another advantage of using the two types of data in conjunction with one another. Any relationships found between turnover and school or organizational variables could, of course, be partly a result of other unobserved factors not included in the analysis. For instance, turnover in private schools might not be due to school effects, but to teacher-selection effects; i.e., those employed in private schools might tend to view teaching 
Teacher Turnover and Teacher Shortages

as a temporary job prior to embarking on a more permanent career. It is not possible to control for all such factors, but it is possible to further explore these issues by taking a more in-depth look at the reasons teachers themselves give for their turnover-the objective of the third stage of the analysis. This stage separately examines both migration and attrition and both voluntary and involuntary departures, and focuses, in particular, on two widely divergent types of schools-small private and urban, high-poverty public schools.

\section{Results}

\section{Levels of Turnover and School Staffing Problems}

Teachers are a relatively large occupation group-they represent $4 \%$ of the entire civilian workforce. There are, for example, more than twice as many $\mathrm{K}-12$ teachers as registered nurses and five times as many teachers as either lawyers or professors (U.S. Bureau of the Census, 1998). Moreover, the rate of turnover for teachers appears to be higher than in many other occupations. One of the best known sources of national data on rates of employee turnover, the Bureau of National Affairs, has shown that nationwide levels of total employee departures have been quite stable over the past decade, averaging 11\% per year (Bureau of National Affairs, 1998). ${ }^{8}$ The data on nationwide employee turnover provide an overall benchmark; however, a more similar point of comparison is nursing, which like teaching is a predominantly female occupation that has experienced perennial workplace staffing problems. A recent survey found the mean turnover rate of registered hospital nurses in the mid 1990s was 12\% (William M. Mercer, 1999). ${ }^{9}$ Comparison of the TFS data with either the nurse's or the employee turnover rate suggests that teaching has a relatively high turnover rate: 15\% from 1988 to $1989,13.2 \%$ from 1991 to 1992, and 14.3\% from 1994 to 1995.

Elsewhere I have reported in detail the SASS data on the levels and variations of school staffing problems-the difficulties schools have adequately staffing classrooms with qualified teachers (Ingersoll, 1995a, 1999). I will briefly summarize these data in order to focus on the topic of particular interest here-the connection between teacher turnover and these school staffing problems.

Consistent with the shortage predictions discussed earlier, data from SASS and other NCES data sources show that demand for teachers has increased since the mid-1980s. Since 1984, student enrollments have increased, most schools have had job openings for teachers, and the size of the teaching workforce $(\mathrm{K}-12)$ has increased, although the rate of these increases began to decline slightly in the late 1990s (Gerald, 1998; Snyder, Hoffman, \& Geddes, 1997, pp. 12-13). Most important, substantial numbers of those schools with teaching openings have experienced difficulties with recruitment. In both 1990-1991 and 1993-1994 about 47\% of those with openings reported some degree of difficulty finding qualified candidates in one or more fields. However, even when the rates of enrollment increases 


\section{Ingersoll}

were at their peak, in any given field only a minority of the total population of schools actually experienced recruitment problems. For instance, the data show that in 1993-1994, 35\% of secondary schools had job openings for English teachers and about one-fourth of these indicated they had at least some difficulty filling these openings-but this represented only $9 \%$ of all secondary schools. Similarly, 34\% of secondary schools had job openings for math teachers and just under half of these indicated they had at least some difficulty filling these math openings-but this represented only $16 \%$ of all secondary schools. Likewise, $27 \%$ of all schools had job openings for special education teachers and just over half of these indicated they had at least some difficulty filling these openings-but this represented only $15 \%$ of all schools. ${ }^{10}$

Moreover, for several reasons, the data suggest that these hiring difficulties were not primarily due to shortages in the technical sense of a teacher supply deficit, driven by student enrollment and teacher retirement increases. First, substantial numbers of schools have had staffing problems in fields such as English and social studies, which have long been known to have overall surpluses.

Second, data from all three cycles of SASS show that the demand for new teachers is not primarily due to student enrollment increases, but to preretirement turnover. The data show that teacher turnover is, numerically, a sizable phenomenon (e.g., from 1994 to 1995, about 418,000 from a force of just under 3 million teachers departed their teaching jobs) and, moreover, that these departures are a major factor behind the demand for new hires. For instance, about 190,000 teachers newly entered the occupation for the 1990-1991 school year. However, in the following 12 months, about 180,000 teachers-equivalent to $91 \%$ of those just hired-left the occupation altogether. In 1993-1994, 3 years later, about 193,000 teachers newly entered the occupation, but in the following 12 months, about 213,000-equivalent to $110 \%$ of those just hired-left the occupation. Finally, although teacher retirements have increased in recent years, they account for only a small portion of total turnover. For example, from 1994 to 1995 there were about 50,000 retirees, accounting for only $24 \%$ of the 213,000 leavers and only $12 \%$ of the total turnover of 418,000 (Ingersoll, 2001a). The image that these data suggest is one of a "revolving door"-an occupation in which there are relatively large flows in, through, and out of schools in recent years, only partly accounted for by student enrollment increases or teacher retirements.

Not all of the flows out of schools result in a permanent loss of teachers. One form of this revolving door is represented by temporary attritionteachers who leave teaching but return in later years (for insightful work on this, see Murnane, Singer, Willett, Kemple, \& Olsen, 1991). Another form of outflow is represented by migrants who move to teaching jobs in other schools, which accounts for about half of the total teacher turnover. ${ }^{10}$ Unlike attrition, teacher migration is a form of turnover that does not decrease the overall supply of teachers because departures are simultaneously new hires. As a result, it would seem reasonable to conclude that teacher migration 
does not contribute to the problem of staffing schools. From a macro and systemic level of analysis, this is probably correct. However, from an organization-level perspective, the data suggest that teacher migration does contribute to the problem of staffing schools.

From the viewpoint of those managing at the school-level, teacher migration and attrition have the same effect-in either case they result in a decrease in staff, which usually must be replaced. A sufficient teacher supply pool would, of course, ease replacement; however, the data suggest that an overall lack of supply is neither the sole, nor dominant factor, behind staffing problems. The degree of staffing problems vary greatly among different types of schools even in the same jurisdiction, and schools ostensibly drawing from the same teacher supply pool can have significantly different staffing scenarios. Other research has found, for example, that in the same metropolitan area in the same year some schools have extensive waiting lists of qualified candidates for their teaching job openings, while other nearby schools have great difficulty filling their teaching job openings with qualified candidates (National Commission on Teaching, 1997). Consistent with this, analysis of variance of the SASS data reveals that the variation in school hiring difficulties is far greater within, than between, states. ${ }^{12}$ Understandably, schools with teacher recruitment problems are also more likely to have teacher retention problems. As mentioned above, the majority of schools do not experience difficulty filling their openings with qualified candidates. But, the data show schools that do report difficulties filling their openings are almost twice as likely to have above-average turnover rates, compared to schools reporting no difficulties. That is, the data show that school staffing difficulties are correlated with higher levels of turnover.

Moreover, the data show that school-to-school differences in turnover are significant. Figure 1 illustrates annual turnover rates (from the 1990-1991 to 1991-1992 school years) for a selection of school types. As a benchmark, it also includes the annual Bureau of National Affairs (BNA) nationwide rate of employee turnover (11\%). For example, high-poverty (poverty enrollment of $50 \%$ or more) public schools have higher turnover rates than do more affluent (poverty enrollment below 15\%) public schools. It is interesting to note that urban public schools have only slightly more turnover than do suburban and rural public schools. More salient are the differences in rates of turnover according to the sector and size of the school. Private schools have higher turnover rates than public schools, and within the private sector, smaller schools have substantially higher rates of turnover than do larger schools. ${ }^{13}$

On one end of the scale lie larger (600 or more students) private schools with among the lowest average turnover rate (about 10\%, which is close to what is found in other occupations). On the other end of the scale lie smaller (fewer than 300 students) private schools. It should be noted that larger private schools represent only a small portion of all private school teachers, whereas smaller private schools represent $81 \%$ of all private schools and $56 \%$ of all private school teachers in the United States. ${ }^{14}$ In rates of turnover, smaller private schools have the highest average levels-about 23\%. The 


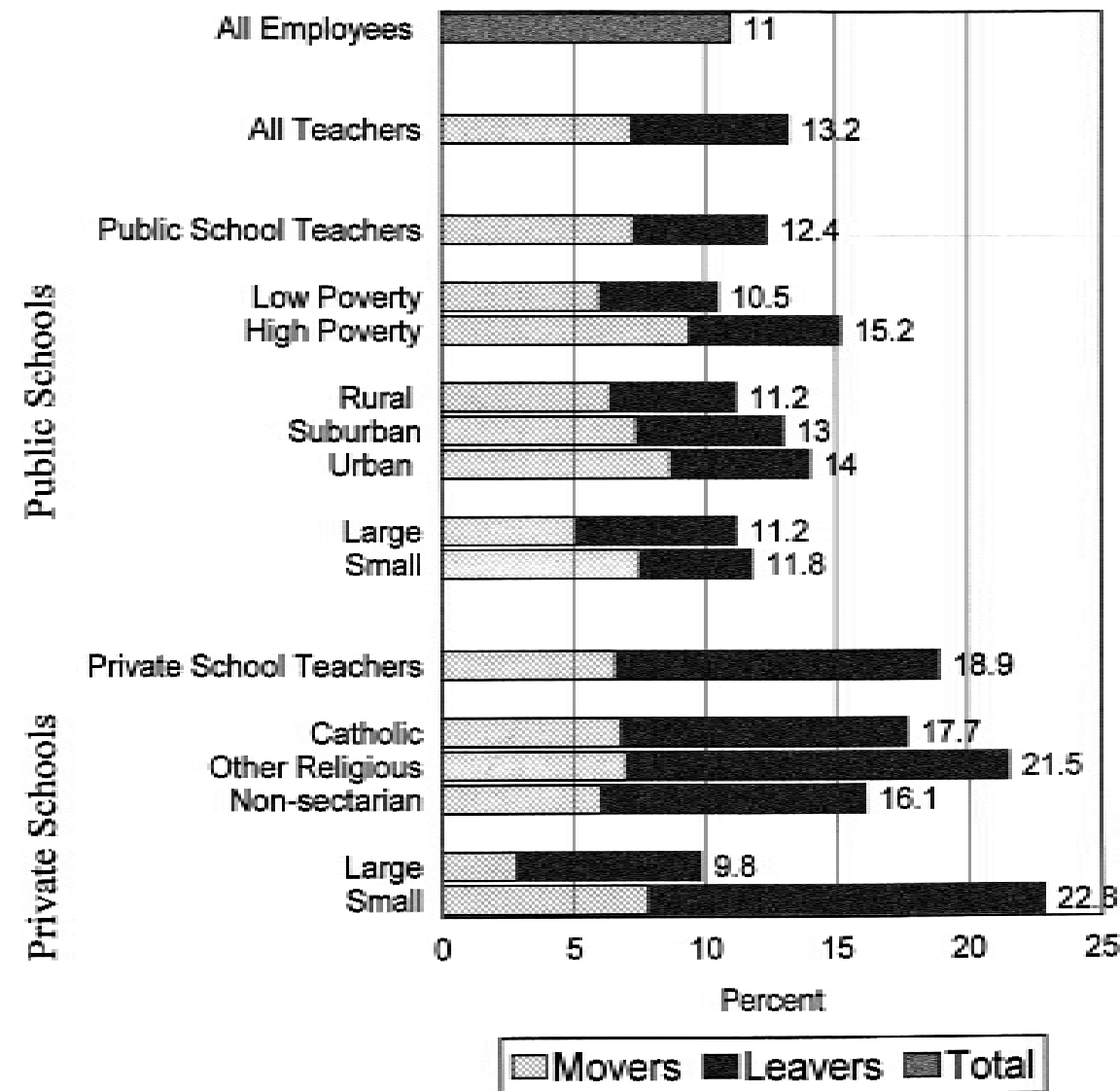

Figure 1. Percentages of annual employee turnover and percentages of annual teacher turnover, by selected school characteristics.

turnover rate in these schools is significantly higher, for instance, than the rate in high-poverty public schools, and is more than double the national average for other kinds of employees. The following section examines the sources of high teacher turnover.

Predictors of Turnover

Table 4 presents six multiple regression models that examine which of the school-to-school differences in turnover rates, described above, remain salient after controlling for the characteristics of teachers, and also whether school organizational conditions are associated with teacher turnover, after controlling for the characteristics of schools and teachers.

In the first model, the relationship between the teacher characteristics as a group (model 1 of Table 4) and the likelihood of turnover is statistically significant (at a 90\% level of confidence). The age of teachers is the most 
Table 4

Logistic Regression Analysis of the Likelihood of Teacher Turnover

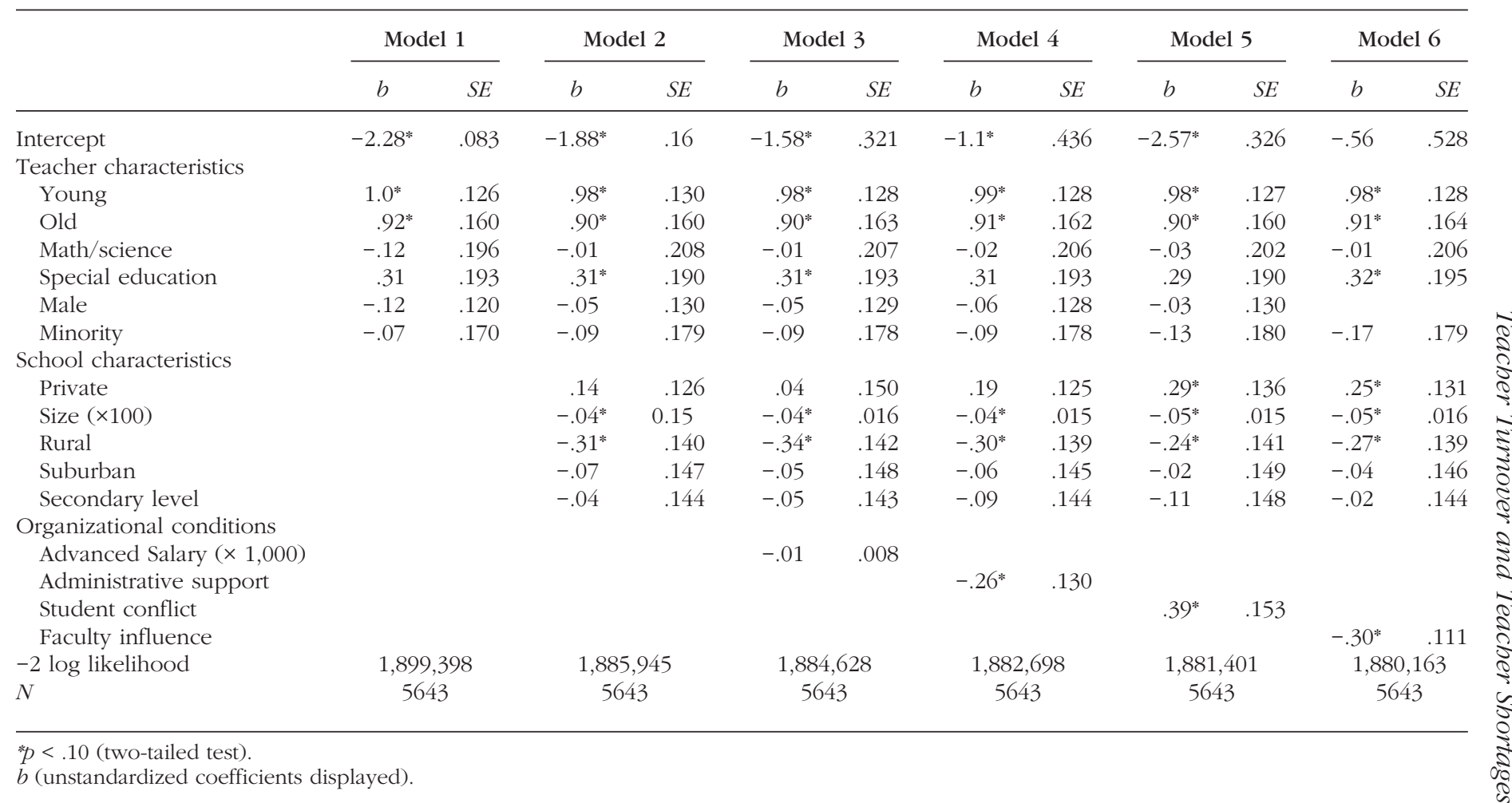




\section{Ingersoll}

salient predictor of the likelihood of their turnover. Both younger (less than 30 years) and older (greater than 50 years) teachers are more likely to depart than are middle-aged teachers. For instance, the relative odds of young teachers departing are $171 \%$ higher than for middle-aged teachers. The analysis also shows that special education teachers are more likely to depart than other teachers, but the coefficient is slightly insignificant in model 1 (it becomes slightly significant in some of the other models). Surprisingly, math and science teachers are not more likely to depart than are other teachers. Male teachers are less likely to depart than are female teachers, and minority teachers are also less likely to depart than are white teachers. These latter three coefficients, however, are small and not statistically significant.

When school characteristics are added to the model as a group (model 2 of Table 4), the model likelihood statistic decreases by a statistically significant amount. School size, in particular, stands out as a key variable. In smaller schools teachers depart at higher rates; an enrollment difference of 100 students is associated with a $4 \%$ difference in the odds of teachers departing. Although there is a strong bivariate positive correlation between private schools and turnover, the coefficient for private schools does not quite achieve statistical significance in model 2. (In later models, after controlling for organizational conditions, it does achieve significance-a point to which I will return). In addition, teachers in rural schools are less likely to turnover than are those in urban schools, but, interestingly, there is little difference in turnover between suburban and urban schools. Finally, the likelihood of turnover from secondary schools is little different than turnover from elementary and $\mathrm{K}-12$ combined schools.

The question of particular interest here is, after controlling for the characteristics of teachers and schools, are the organizational conditions of schools associated with turnover? Models 3-6 of Table 4 address this question. Each of the four measures of school organizational conditions is examined in a separate model in order to avoid the problem of multicollinearity among them. In each of the models shown, the introduction of the organizational variable reduces the model likelihood statistic by a statistically significant amount; moreover, after controlling for the characteristics of teachers and schools, three of the four conditions remain significantly associated with turnover.

Although the measure for advanced salaries has a statistically significant negative bivariate correlation with turnover, once other factors are controlled as shown in model 3, the coefficient for advanced salaries (the school's normal yearly base salary provided to teachers with a masters degree and 20 years of experience) is no longer statistically significant (at a 90\% level of confidence). As shown in model 4, in schools that provide more administrative support to teachers, turnover rates are distinctly lower. A 1-unit difference between schools in reported support (on a 4-unit scale, see Table 2) is associated with a $23 \%$ difference in the odds of a teacher departing. As shown in model 5, in schools with lower levels of student discipline problems, turnover rates are distinctly lower. A 1-unit difference in reported 
student discipline problems between two schools (on a 4-unit scale) is associated with a $47 \%$ difference in the odds of a teacher departing. Finally, as shown in model 6, schools with higher levels of faculty decision-making influence and autonomy have lower levels of turnover. A 1-unit difference in reported teacher influence between schools (on a 6-unit scale) is associated with a $26 \%$ difference in the odds of a teacher departing.

Once these organizational conditions are controlled, some of the coefficients for school characteristics (in model 2) change; in particular, the coefficient for private schools. In model 3, once salary is controlled, the coefficient for private schools decreases and becomes very insignificant, suggesting that low salaries account for some of the turnover in private schools. In each of models 4, 5, and 6, once the organizational condition is controlled, the coefficient for private schools increases and in each case achieves or comes close to achieving statistical significance. This suggests that the rate of turnover in private schools may be ameliorated by their higher levels of administrative support, higher levels of faculty influence, and lower levels of student discipline problems and, hence, once these are controlled, the rate of turnover in these schools increases.

I also tested models 3-6 with several teacher subsets: public school teachers only, private school teachers only, movers only, leavers only, and finally, voluntary departures only. (These models are not shown here; copies can be obtained from the author). Notably, in each subset I found similar results in regard to the association of the four organizational conditions with turnover.

The separate models of turnover for public and private schools examined in more detail what accounts for differences in turnover within each school sector and to what extent the coefficients differ across sectors (see also Ingersoll, 1995a, 2001a). For public schools, I included additional variables for the district size and the level of poverty of the student population. For private schools, I included additional dummy variables for the orientation or affiliation of the school (Catholic, other religious, and nonsectarian).

The results showed that among public schools, teachers in high-poverty schools have higher rates of turnover than do those in more affluent public schools. ${ }^{15}$ Notably, the coefficients for both suburban schools and district size were positive, but neither was strong or significant. Among private schools, both non-Catholic and Catholic religious schools appeared to have more turnover than did nonsectarian private schools, but in most of the models these coefficients did not quite achieve significance. Notably for the focus of this analysis, in both sectors the effects of the four organizational conditions were significant, in the expected direction, and in most cases strong (with the exception of advanced salaries among public schools).

I also estimated the same set of models for movers and leavers separately to explore differences in the predictors of each. The data indicate a few interesting differences. For instance, private school teachers were more likely to leave teaching altogether, but less likely to move to other schools, than were public school teachers. Notably, although both special education 


\section{Ingersoll}

and math/science teachers were more likely to migrate than other kinds of teachers, neither was more likely to leave teaching altogether than other teachers, once other factors were controlled. But overall, the models indicated that many of those who were more likely to move from their teaching jobs were also more likely to leave their jobs. In particular, organizational conditions associated with higher rates of teacher migration were similarly associated with higher rates of teacher attrition.

Finally, I also estimated the same set of models for voluntary departures only. This subset of turnover excluded those departing because of retirement, layoffs, terminations or school closings. When examining departures that are, ostensibly, a matter of choice, one would expect organizational conditions to have a stronger relationship. The data show that this is the case; while many of the other factors changed little, the association of the four organizational measures all increased. Unlike in the overall turnover sample, school-to-school differences in advanced teacher salaries were significantly associated with voluntary turnover; a difference of $\$ 1,000$ was associated with a difference of $3 \%$ in the odds of teachers voluntarily departing. However, this relationship is still modest relative to the changes associated with school-to-school differences in the other organizational conditions. For example, a 1-unit difference (on a 4-unit scale) in reported student discipline problems between two schools was associated with a 88\% difference in the odds of a teacher voluntarily departing.

\section{Reasons for Turnover}

The analysis thus far has established the magnitude of teacher turnover and indicated its association with organizational conditions, after controlling for the characteristics of schools and teachers. The next stage presents a more in-depth look at the reasons teachers themselves give for their turnover. Utilizing self-report data in conjunction with the prior regression analyses (based on data from a larger set of respondents) provides a means of comparing the two sets of findings. As before, the analysis' primary focus is on the strength and consistency of the relationship between turnover and school organizational conditions, across different kinds of schools and across different subsets of turnover. However, rather than present data on a wide range of school comparisons, this section focuses on two particular types of schools-urban, high-poverty public schools and small private schools. These two types of schools are often juxtaposed as extreme opposites (e.g., Bryk, Lee, \& Smith, 1990), and the results of the preceding analysis show that their rates of turnover also diverge. This section more closely examines the reasons teachers report for both migration and attrition and for both voluntary and involuntary departures in these schools.

Table 5 presents data on the annual rates of and self-reported reasons for both teacher migration and attrition for all schools; for high-poverty, urban public schools; and for small private schools. In addition, for all teachers who departed because of job dissatisfaction, the bottom portion of the table presents data on the self-reported reasons for their dissatisfaction. ${ }^{16}$ 
Teacher Turnover and Teacher Shortages

Table 5

Percentages of Teacher Turnover and Percentages of Teachers Reporting Various Reasons for their Turnover, by School Type

\begin{tabular}{|c|c|c|c|c|c|c|}
\hline & \multicolumn{2}{|c|}{ All schools } & \multicolumn{2}{|c|}{$\begin{array}{l}\text { Urban, high-poverty } \\
\text { public schools }\end{array}$} & \multicolumn{2}{|c|}{$\begin{array}{l}\text { Small } \\
\text { private schools }\end{array}$} \\
\hline & Movers & Leavers & Movers & Leavers & Movers & Leavers \\
\hline Rates of turnover & 7.2 & 6.0 & 8.7 & 5.7 & 7.8 & 15.0 \\
\hline \multicolumn{7}{|l|}{ Reasons for turnover } \\
\hline Retirement & - & 27 & - & 32 & - & 8 \\
\hline School staffing action & 41 & 12 & 34 & 5 & 22 & 13 \\
\hline Personal & 33 & 45 & 40 & 41 & 42 & 51 \\
\hline To pursue other job & 25 & 24 & 28 & 28 & 27 & 31 \\
\hline Dissatisfaction & 27 & 25 & 29 & 19 & 56 & 23 \\
\hline \multicolumn{7}{|l|}{ Reasons for dissatisfaction } \\
\hline Inadequate administrative support & 38 & 30 & 25 & 18 & 25 & 34 \\
\hline Poor salary & 47 & 45 & 24 & 46 & 79 & 73 \\
\hline Student discipline problems & 18 & 30 & 29 & 27 & 3 & 12 \\
\hline Lack of faculty influence & 13 & 18 & 26 & 11 & 12 & 9 \\
\hline Lack of student motivation & 10 & 38 & 27 & 50 & 3 & 14 \\
\hline Class sizes too large & 6 & 13 & 8 & 7 & .5 & 13 \\
\hline Inadequate time to prepare & 10 & 23 & 8 & 8 & 4 & 18 \\
\hline Unsafe environment & 11 & 2 & 10 & 26 & 1 & 0 \\
\hline \multicolumn{7}{|l|}{ Poor opportunity for professional } \\
\hline advancement & 9 & 10 & 5 & 24 & 15 & 9 \\
\hline Lack of community support & 12 & 5 & 11 & 0 & 2 & 1 \\
\hline Interference in teaching & 5 & 5 & 12 & 1 & 8 & 4 \\
\hline \multicolumn{7}{|l|}{ Lack of professional competence } \\
\hline of colleagues & 8 & 4 & 23 & 10 & 5 & 4 \\
\hline Intrusions on teaching time & 5 & 11 & 7 & 7 & 2 & 1 \\
\hline
\end{tabular}

The overall turnover rate is $13.2 \%$ (migration of $7.2 \%$ plus attrition of $6.0 \%$ ). The overall rate of teacher turnover in urban, high-poverty public schools is slightly above average (14.4\%) and the overall rate in small private schools is significantly higher (22.8\%). This rate gap between urban, highpoverty public and small private schools is almost entirely due to differing levels of attrition, rather than migration. The migration rate for teachers in urban, high-poverty public schools, like that for all teachers, is only slightly different from that of teachers in small private schools $(8.7 \%$ compared to $7.8 \%$ ). However, teachers in small private schools leave the teaching occupation at a rate more than double that of teachers in urban, high-poverty public schools (15\% compared to 5.7\%). As expected, there are differences in the reasons for these types of flows from each type of school, but there are also some prominent commonalities, as summarized below.

Among the least prominent reasons for turnover is retirement. The latter actually accounts for less than one-third of those leaving the occupation (27\%) and only a small part (12\%) of total turnover (movers and leavers). Retirement also does not account for the relatively high rates of attrition in small private schools. Indeed, urban, high-poverty public schools have far 
Ingersoll

higher levels of retirement turnover than do small private schools $(32 \%$ compared to $8 \%$ ).

School staffing cutbacks due to lay-offs, school closings, and reorganizations account for a larger proportion of turnover ( $41 \%$ of migration and $12 \%$ of attrition) than does retirement. Moreover, this kind of turnover provides some explanation for the high rates of attrition in small private schools. More than twice as much attrition in private schools is reported due to staffing actions as is reported in urban, high-poverty public schools. Some of this difference may be a result of private school administrators laying off low-performing staff - a capability held to be less available to public school administrators (Chubb \& Moe, 1990). However, the data also show that, overall, staffing actions account for only a small portion of attrition in either type of school (5\% and 13\%). Staffing actions more often result in migration to other teaching jobs rather than leaving the teaching occupation altogether, and these cross-school movements are more common in urban, highpoverty public schools than in small private schools (34\% compared to 22\%). The former's higher rates of school staffing migration are most likely a result of within-school district transfers, a type of flow rarely found in private school systems.

Personal reasons, such as departures for pregnancy, child rearing, health problems, and family moves, are more often reported as reasons for turnover than either retirement or staffing actions (33\% of migration and 45\% of attrition). Moreover, this kind of turnover also provides some explanation for the high rates of attrition in small private schools. Teachers in small private schools are slightly more likely to depart for personal reasons than are those in urban, high-poverty public schools ( $51 \%$ compared to $41 \%$ ), but the data also show that these motives are common to all schools.

Finally, two inter-related reasons tied to the organizational conditions of teaching are, together, the most prominent source of turnover. Forty-two percent of all departures report as reasons job dissatisfaction or the desire to pursue a better job, another career, or to improve career opportunities in or out of education. Dissatisfaction underlying migration is most often listed as being due to low salaries, lack of support from the school administration, student discipline problems, and lack of teacher influence over decisionmaking. Likewise, dissatisfaction underlying attrition is most often reported as being due to low salaries, lack of support from the school administration, lack of student motivation, and student discipline problems. These findings from the self-report data are highly consistent with the results in the prior regression models, lending confidence to both stages of the analysis.

Similar proportions of teachers in urban, high-poverty public schools and small private schools report departing in order to pursue a better job or other career opportunities, but surprisingly, far more turnover in small private schools is linked to job dissatisfaction than in urban, high-poverty public schools. Why is this so?

For teachers in urban, high-poverty public schools, the reasons given for the dissatisfaction underlying their turnover are not surprising. Of those 
who depart due to job dissatisfaction, one-fourth or more report each of the following five reasons: low salaries; a lack of support from the administration; student discipline problems; lack of student motivation; and lack of influence over decision-making. However, several factors stand out as not serious enough to lead to much turnover in these schools: large class sizes, intrusions on classroom time, lack of planning time, lack of community support, and interference with teaching.

In contrast, although a larger portion of those departing small private schools indicated they do so from job dissatisfaction, the major reasons for their dissatisfaction are fewer in number. Most prominent is salary. About three-fourths of those departing small private schools from job dissatisfaction report poor salaries as a reason. The SASS data indicate that in 1993-1994, the average starting salary for a teacher with a bachelor's degree and no experience in a small private school was about $\$ 16,000$, and the average maximum salary (the highest offered by the school to any teacher) was about $\$ 28,000$. In contrast, in the same year, the average starting salary for a teacher with a bachelor's degree and no experience in public schools was about $\$ 22,000$, and the average maximum salary was about $\$ 40,500$. Low salaries are not the only reason given for the relatively high levels of dissatisfactionrelated turnover in small private schools, however. About one-third of the dissatisfied teachers indicate that a lack of support from the school's administration led to their departure.

In sum, teachers report they depart their jobs for a variety of reasons. As expected, there are differences between movers and leavers and differences between small private and urban poor public schools. But what is noteworthy is the amount of similarity in the results across different types of schools, across different types of turnover, and across different types of data. Retirement accounts for a relatively small number of departures, a moderate number of departures are reportedly due to school staffing actions, a larger proportion of teachers indicate they depart for personal reasons, and an even larger proportion report they depart either because they are dissatisfied with their jobs or in order to seek better jobs or other career opportunities.

\section{Discussion and Implications}

The objective of this study is two-fold: to first establish the role of teacher turnover in the staffing problems of schools and then to closely examine the role of school characteristics and organizational conditions in teacher turnover. As reviewed earlier, there are two educational issues, important in both the realms of research and policy, for which this study has implicationsteacher shortages, and school community and effectiveness. These implications are discussed below.

\section{Teacher Turnover and Teacher Shortages}

Since the early 1980s, educational theory has predicted that shortfalls of teachers resulting primarily from two converging demographic trendsincreasing student enrollments and increasing teacher retirements—will lead 


\section{Ingersoll}

to problems staffing schools with qualified teachers and, in turn, lower educational performance (e.g., National Commission on Excellence in Education, 1983; National Commission on Teaching, 1997). Concern over shortages has given impetus to empirical analysis, much of it focused on teacher turnover (e.g., Grissmer \& Kirby, 1987, 1992, 1997; Heyns, 1988; Murnane, 1981, 1987; Murnane, Singer, \& Willett, 1988). This analysis attempts to build on these bodies of theory and research by examining teacher turnover and, in turn, school staffing problems from an organizational perspective.

The data show that teacher turnover is a significant phenomenon and a dominant factor driving demand for new teachers and, in turn, creating school staffing problems. Although it is true that student enrollments are increasing, the demand for new teachers is primarily due to teachers moving from or leaving their jobs at relatively high rates. Consistent with prior empirical research (e.g., Bobbitt, Leich, Whitener, \& Lynch, 1994; Hafner \& Owings, 1991; Grissmer \& Kirby, 1987, 1992, 1997; Murnane, Singer, \& Willett, 1988), the analysis indicates that teacher characteristics, such as specialty field and age, are associated with a significant amount of turnover. Teacher retirements, in particular, stand out. But, net of the effects of these teacher characteristics, there are also significant effects of school and organizational characteristics on turnover which have largely been overlooked by previous theory and research. Although it is true that teacher retirements are increasing, the overall amount of turnover related to retirement is relatively minor when compared to that associated with other factors, such as teacher job dissatisfaction and teachers seeking to pursue better jobs or other careers.

I have compared these findings, which are from the 1990-1992 cycle of SASS/TFS with the results of analyses I've undertaken with the other (19871989 and 1993-1995) cycles of the survey. This included comparisons of the self-report data on teachers' reasons for turnover for all three cycles of TFS/SASS and parallel regression modeling with data from the first two cycles. Because most of the items used in this analysis were included in the first two cycles, I was able to estimate the same models with these independent data sources. Moreover, the first two cycles of SASS provide a separate school-level turnover rate based on school principals' reports of the percentage of their teaching staff that separated from their schools. I also estimated similar models using both ordinary least-squares and logistic multiple regression with this school-level measure of turnover as the dependent variable (see, e.g., Ingersoll, 1995a, 2001a, 2001b). In all of these analyses-for different data cycles and with different types of dependent variables-I found the results to be very similar to those reported here. Notably, my major findings on school and organizational effects were all confirmed.

These findings suggest that teacher supply and demand imbalances and attendant school staffing problems are neither synonymous with, nor primarily caused by, teacher shortages in the technical sense of a supply-side deficit of qualified candidates. Moreover, this analysis suggests that increases in student enrollment and increases in teacher retirement are not the primary factors at the root of staffing difficulties, as current educational theory holds. 
Rather than insufficient supply, the data suggest that school staffing problems are primarily due to excessive demand resulting from a "revolving door"-where large numbers of teachers depart their jobs for reasons other than retirement.

The findings of this analysis have important implications for educational policy. Supply and demand theory holds that where the quantity of teachers demanded is greater than the quantity of teachers supplied, there are two basic policy remedies: increase the quantity supplied or decrease the quantity demanded. As noted in the beginning of this article, teacher recruitment, an example of the former approach, has been and continues to be the dominant approach in addressing school staffing inadequacies (Hirsch et al., 2001; Feistritzer, 1997; Kopp, 1992). To be sure, some schools in some jurisdictions suffer from inadequate numbers of qualified teachers supplied. A case in point is California, where increased hiring due to initiatives to reduce elementary school class sizes has created a temporary imbalance between supply and demand. However, this analysis suggests that recruitment programs alone will not solve these or other school staffing problems if they do not also address the problem of teacher retention. The data show that the solution to staffing problems does not primarily lie in increasing an insufficient supply, but rather in decreasing excess demand. In short, this analysis suggests that recruiting more teachers will not solve staffing inadequacies if large numbers of such teachers then leave.

Current policies will not only fail to solve school staffing problems, but this analysis suggests that they also divert attention from the primary underlying problem - the manner in which teachers and schools are managed. From the perspective of this analysis, schools are not simply victims of large-scale, inexorable demographic trends, and there is a significant role for the management of schools in both the genesis and solution of school staffing problems. Rather than increase the quantity of teacher supply, an alternative solution to school staffing problems, implied by this analysis, is to decrease the demand for new teachers by decreasing turnover. The data suggest that improvements in organizational conditions, such as increased support from the school administration, reduction of student discipline problems, and enhanced faculty input into school decision-making and increased salaries, would all contribute to lower rates of turnover, thus diminish school staffing problems, and ultimately aid the performance of schools. Although the data suggest that these changes would be beneficial, they do not imply they will be easily achieved. Indeed, it may be that because such reforms are considered too costly in one manner or another for important constituencies, that they have often been overlooked in research and reform concerned with school staffing problems.

\section{Teacher Turnover, School Community, and School Effectiveness}

The results of this analysis also have implications for a second area of education theory and policy—school community and effectiveness. Educational 


\section{Ingersoll}

sociologists, in particular, have long held that the presence of a sense of community and cohesion among families, teachers, and students is important for the success of schools (e.g., Durkheim, 1961; Waller, 1932; Parsons, 1959; Coleman \& Hoffer, 1987; Grant, 1988; Rosenholtz, 1989). In general, large public schools, especially those in urban, high-poverty areas, are often cited as less likely to exhibit a sense of community (e.g., Bryk, Lee, \& Smith, 1990). In contrast, many have argued that small schools are more likely to have a communal climate, providing support for a "small is beautiful" viewpoint perennially popular among educational reformers (for reviews of the debate on school size, see Bryk, Lee, \& Smith, 1990; Guthrie, 1979; Walberg $\&$ Walberg, 1994). Moreover, some researchers have tied the effectiveness of private schools, especially the religiously oriented, to a coherent and unified mission and sense of community (e.g., Bryk, Lee, \& Holland, 1993; Coleman \& Hoffer, 1987).

Underlying my analysis is the premise, drawn from the sociology of organizations, occupations, and work, that high levels of employee turnover are tied to how well organizations function. From this perspective, high rates of teacher turnover are of concern not only because they may be an indication of underlying problems in how well schools function, but also because they can be disruptive, in and of themselves, for the quality of school community and performance. This analysis, however, does not explicitly examine the relationships among teacher turnover, school community, and school effectiveness. But, if one accepts the above premise, then the results of this analysis raise serious questions for the educational literature on school community and, especially, concerning which kinds of schools are more likely to have a positive sense of community and what effect teacher attachment to schools has on school community and performance.

The data show that neither larger schools, public schools in large school districts, urban public schools, nor high-poverty public schools have the highest rates of teacher turnover. In contrast, small private schools stand out for their relatively high rates of turnover. Moreover, among private schools there are large variations in turnover. In contrast to the relatively low turnover rates in large private schools, small private schools lose, on average, almost one-fourth of their faculty each year, most of whom are full-time employees. In such cases, ostensibly, an entire staff could change within a school in only a short number of years. Small private schools employ about $7.5 \%$ of the K-12 teaching force, but account for about 13\% of all teacher turnover. Thus they have a small but disproportionate contribution to system-wide teacher supply and demand imbalances. But, in addition, high levels of teacher turnover in small private schools are of both theoretical and policy concern because these are the very schools that presumably are most likely to have a performance-enhancing, tight-knit community. Notably, in previous research I have found that private school teachers are far more likely to switch to public school jobs than public school teachers are to switch to private school jobs. Indeed, almost half of those who migrate from private school teaching jobs to other teaching jobs move to public schools 
Teacher Turnover and Teacher Shortages

(Ingersoll, 1995a). These findings stand out because teachers in private schools consistently report higher levels of job satisfaction and more positive school climates than do teachers in other kinds of schools (e.g., Ingersoll, 1997; Reyes, 1990).

What accounts for these findings? This analysis indicates that one reason for high rates of turnover in small private schools is teacher compensation. The data suggest that, despite high levels of job satisfaction, some teachers in small private schools depart because they cannot afford to remain. The data in Table 5 also indicate, however, that low salaries are not the only reason for the high level of turnover in small private schools. Significant numbers of those who depart their jobs in these schools report they are dissatisfied with the administration of their school. What explains these surprisingly high levels of dissension between teachers and administrators in small private schools?

Below I offer an explanation as a hypothesis for future empirical investigation. This hypothesis is drawn from my research on the organizational and occupational conditions in schools (Ingersoll, 1996, 2001b) and also from my own experiences as a former secondary-school teacher in both public and private schools. High levels of teacher turnover in small private schools may, paradoxically, be caused by a coherent mission, clearly defined values, and a tight-knit sense of community.

Numerous analysts have pointed out the negative consequences of the impersonal, alienated, "shopping mall," organizational climate often found in large public schools (e.g., Bryk, Lee \& Smith, 1990). Another characteristic often found in this kind of organization, however, is diversity. Organizations without a coherent mission, clearly defined values, or a tight-knit sense of community may, intentionally or unintentionally, allow more choice and be more tolerant of differences. From the viewpoint of teachers, larger public schools lacking such coherence and community may provide more academic freedom and more career options. To use Hirschman's classic (1970) framework, members who disagree with the policies of an organization face three basic options: exit, voice, or loyalty. For teachers who disagree with school policies, large public schools may be more likely to provide options, other than either conformity to existing policies or exit from the job. Moreover, simply by virtue of their size, large schools and large school systems may also offer more job and mobility opportunities for teachers either within the school or within the district.

In contrast, a coherent mission, clearly defined values, and a tight-knit sense of community may be a source of strength and success in small and religious private schools, as argued by Coleman and Hoffer (1987), but may also be a source of conflict. Emphasizing one set of goals, values, policies, and programs, by definition, results in de-emphasizing others. From the viewpoint of teachers, key questions are these: Whose policies are emphasized by the school? What options and choices are available for those who disagree with the dominant policies, values, and goals? My hypothesis, reflecting the organizational perspective of this analysis, is that teacher's 


\section{Ingersoll}

choices to stay or exit are shaped by particular occupational and organizational conditions in schools. For instance, if the school provides mechanisms for the protection of academic freedom and job security (such as tenure), and mechanisms for voicing opposition (such as teacher unions), those who disagree with school policies will be less likely to exit. However, if there are few mechanisms for the collective or individual expression of disagreement with school policies and few protections for those employees who challenge school policies, those who disagree with school policy will be more likely to exit. My hypothesis is that small and religious private schools are less likely to have teacher unions, tenure provisions, formal mechanisms for collective opposition to school policies, or faculty grievance procedures and, as a result, have higher rates of teacher turnover.

Finally, this study raises another fundamental question: What impact do high rates of teacher turnover have on schools? My analysis has focused on the effects of school and organizational characteristics on teacher turnover, but the reverse is also an important issue and focus in organizational research (e.g., Price, 1989). This is especially pertinent for the case of private schools: What effects do turnover have on the community and performance of these kinds of schools? Of course, the departure of individuals who do not share the goals and values of the organization can be useful to maintain a coherent mission and sense of purpose. After reaching a certain threshold level, however, turnover may become a source of group disintegration, rather than group integration. At such a point, the negative consequences of turnover for organization stability and coherence would begin to overshadow the positive consequences for the organization resulting from the elimination of dissension. It is unclear, of course, where this threshold point is for schools, regardless of size and type. The organizational literature suggests that turnover rates of, for example, almost $25 \%$ will likely have a negative impact on organizational performance, especially if these are organizations, such as schools, for which coherence and continuity are deemed important for effectiveness (e.g., Mobley, 1982). To my knowledge there have been no studies that use national data to examine the impact of teacher turnover on school community and school performance. Such research could address vital questions: How well are schools able to cope with a recurring loss of staff and a recurring need to rehire? What does continual turnover mean for the ability of the teaching staff to establish teamwork and continuity of curricula and programs? How does the loss of teachers affect ties to parents, students, and the community?

\section{Notes}

This research was partly supported by the Center for the Study of Teaching and Policy under the Educational Research and Development Centers Program, PR/Award R308B70003, as administered by the National Institute on Educational Governance, Finance, Policymaking and Management, Office of Educational Research and Improvement, U.S. Department of Education. This article draws from a research report published by the center. Earlier versions of this paper were presented at the annual meeting of the American 


\section{Teacher Turnover and Teacher Shortages}

Sociological Association, August 1997, and the annual meeting of the American Educational Research Association, April 2000. Thanks are due to Linda Grant, William Finlay, James Price, and Mike Knapp for helpful comments on earlier drafts of this paper. Opinions reflect those of the author and do not necessarily reflect those of the granting agencies.

${ }^{1}$ An important exception to this general trend is the recent empirical work of Boe, Bobbitt, Cook, Barkanic, and Maislin (1998), which presents an unusually thorough look at the effects of a range of factors on teacher turnover.

${ }^{2}$ Steers and Momday (1981) calculated that, by 1981, well over 1,000 studies of employee turnover had been done.

${ }^{3}$ Other reports from this larger project focus upon overall levels of teacher supply, teacher turnover and teacher qualifications (Ingersoll, 1995a); levels and causes of underqualified teachers (Ingersoll, 1999); turnover among math/science teachers (Ingersoll, 2000); and overall teacher turnover (Ingersoll, 2001a).

${ }^{4}$ For details on the TFS, see Bobbitt, Leich, Whitener, and Lynch (1994).

${ }^{5}$ Note that the distinction between voluntary and involuntary is difficult to capture empirically (for discussion, see, e.g., Kalleberg and Mastekaasa, 1998; Price, 1997). For example, although most assume that retirements are involuntary, some categorize them as voluntary. Moreover, respondents may not accurately report whether they were laid off, were fired, or retired. Here, I examine these types both together and separately and compare both school-level and teacher self-report data.

${ }^{6}$ See Price, 1997, pp. 532-537, for a discussion of different subsets and definitions of turnover.

${ }^{7}$ This is an important distinction, and it should also be noted that the measure of teacher salary utilized in this analysis is unusual. Teacher salary levels are often standardized according to a uniform salary schedule, based on the education levels and years of experience of the teachers. Especially with an aging teaching workforce, it can be unclear if differences in average salary levels are due to real differences in the compensation offered to comparable teachers at different schools or are due to differences in the experience and education levels of the teachers employed. That is, a school with older teachers may appear to offer better salaries, when, in fact, it does not. A more effective method of comparison across schools is to compare the normal salaries paid by schools to teachers at common points in their careers.

In this analysis I tested three salary measures - each based on a different point on school salary schedules: (a) the normal yearly base salary for a teacher with a bachelor's degree and no experience; (b) the normal yearly base salary for a teacher with 20 years of experience and a master's degree; and (c) the normal yearly base salary for a teacher at the highest possible step on salary schedule. The second measure had a slightly stronger association with turnover than either the first or third, and hence, it is used in this paper. This measure represents the organizational financial rewards teachers can look forward to at an advanced point in their careers if they stay in their particular schools and, hence, could affect their decisions to depart or stay.

This measure also may have limitations. Some economists, for instance, might argue that school salary schedules do not accurately capture the effect of salary on rates of teacher turnover because candidates can obtain this information in deciding whether to accept a particular teaching job. From this viewpoint, since public school teachers are compensated according to published salary schedules that change only infrequently, new entrants can predict with almost complete certainty how much they will be paid in each year in the future. Therefore, if a teacher did accept a job, it suggests that he or she is satisfied with the school's salary levels and, hence, it is most likely that low salaries would not be a factor in future turnover.

On the other hand, sometimes teachers may, of course, accept jobs with salaries below what they would prefer and then move in a few years when a better paying job opens up. Goodlad (1984) and others have argued that, although money is not a major factor in teachers' choice of a job, it is a major factor in their decision to move or leave teaching. In this view, beginning teachers are primarily motivated by nonpecuniary and altruistic values, but if these kinds of expectations are frustrated, salaries can become a source of 


\section{Ingersoll}

considerable dissatisfaction. Therefore, from this viewpoint, salary schedules would be related to turnover precisely because they allow teachers to predict how much they will be paid in the future. This analysis does not presume the validity of either view, but simply tests whether differences in advanced salaries among schools are related to turnover.

${ }^{8}$ The Bureau of National Affairs, a leading research and information service for both business and nonbusiness organizations, has gathered data on employee turnover for more than two decades through quarterly surveys of human resource and employee relations executives. Its 1997 fourth-quarter survey, for example, included 230 respondents representing about 300,000 employees from a wide range of organizations. The latter vary in size from those employing less than 100 to those employing thousands and include manufacturing, nonmanufacturing, finance, and healthcare establishments. Turnover is defined in terms of those who depart the organization and includes both migration to other organizations and those leaving the occupation altogether. Perhaps the best, albeit now dated, source of comparative data on occupational turnover rates is Chapter 4 of Price's seminal 1977 study on employee turnover.

${ }^{9}$ William M. Mercer, a leading human resource consulting firm, conducts research on hospital and nurse staffing issues in conjunction with the American Nurses Association and the American Organization of Nurse Executives, a division of the American Hospital Association. The data reported here are from the Survey of Registered Nurse Attraction and Retention conducted by Mercer in August 1999. The sample included human resource executives in 185 healthcare organizations. Of these organizations, 93\% were hospitals, 2\% were long-term care providers, $2 \%$ were ambulatory organizations, and 3\% were home health providers. The median gross revenue of these organizations was $\$ 193$ million, and the median number of full-time employees was 1800 .

${ }^{10}$ The data on school hiring difficulties from the 1993-1994 SASS school questionnaire asked school officials "how difficult or easy it was to fill the vacancies for this school year" in each of 14 fields. I counted as having "difficulty filling teaching vacancies" all those schools reporting "somewhat difficult," "very difficult," or "could not fill." The results were very similar to those obtained from similar items in both the 1987-1988 and 1990-1991 SASS data. The extent to which a school has hiring difficulties is perhaps one of the best indicators of staffing problems. However, it is, of course, not the only indicator of these problems. Elsewhere I examine in detail another indicator of school staffing problems - the extent of the use of underqualified teachers in classrooms (see Ingersoll, 1999).

${ }^{11}$ Elsewhere I analyze in more detail the dynamic nature of teacher turnover and more closely examine the data showing the number, type, and magnitude of the flows of teachers into, through, and out of schools (see Ingersoll, 1995a).

${ }^{12}$ On the basis of a one-way random effects ANOVA model, the data show that the variance component within states was 44 times the size of the variance component between states. Intraclass correlation $=.022$.

${ }^{13}$ In Figure 1, large schools are defined as those with 600 or more students; small schools are those with fewer than 300 students. High-poverty refers to schools with a poverty enrollment of $50 \%$ or more; low-poverty refers to schools with a poverty enrollment below $15 \%$. Middle categories of size and poverty are omitted in the figure. Note that size and poverty are categorized here for purposes of illustration; they are treated as continuous variables in the forthcoming regressions.

${ }^{14}$ These school population proportions are estimates derived from SASS.

${ }^{15}$ In addition to public schools in low-income and high-poverty communities, many have also argued that predominantly minority public schools also have very high levels of teacher turnover (e.g., Rosenholtz, 1985; Kozol, 1991). Because a school's poverty enrollment is very highly intercorrelated with its minority enrollment, I tested the effect of the latter factor on turnover in a separate model. The relationship between percent minority enrollment and turnover was positive and statistically significant, but not strong.

${ }^{16}$ Note that the column segments in Table 5 displaying the percentages reporting various reasons for turnover each add up to more than $100 \%$, because respondents could indicate up to three reasons for their departures. The same applies to the columns displaying reasons for dissatisfaction. 
Teacher Turnover and Teacher Shortages

\section{References}

Bacharach, S., \& Bamberger, P. (1990). Exit and voice: Turnover and militancy intentions in elementary and secondary schools. Educational Administration Quarterly, 26, 316-344.

Bidwell, C. (1965). The school as a formal organization. In J. March (Ed.), Handbook of Organizations (pp. 973-1002). Chicago, IL: Rand McNally.

Bidwell, C., \& Quiroz, P. (1991). Organizational control in the high school workplace: A theoretical argument. Journal of Research on Adolescence, 1, 211-229.

Bluedorn, A. C. (1982). A unified model of turnover from organizations. Human Relations, 35, 135-153.

Bobbitt, S., Leich, M., Whitener, S., \& Lynch, H. (1994). Characteristics of stayers, movers, and leavers: Results from the teacher follow up survey, 1991-92. Washington, DC: National Center for Education Statistics.

Boe, E., Bobbitt, S., \& Cook, L. (1997). Whither didst thou go? Journal of Special Education, 30, 371-389.

Boe, E., Bobbitt, S., Cook, L., Barkanic, G., \& Maislin, G. (1998). Teacher turnover in eight cognate areas: National trends and predictors. Philadelphia, PA: University of Pennsylvania, Center for Research and Evaluation in Social Policy.

Boe, E., \& Gilford, D. (1992). Teacher supply, demand and quality. Washington, DC: National Academy Press.

Braverman, H. (1974). Labor and monopoly capitalism. New York: Monthly Review Press.

Bryk, A., Lee, V., \& Holland, P. (1993). Catholic schools and the common good. Cambridge, MA: Harvard University Press.

Bryk, A., Lee, V., \& Smith, J. (1990). High school organization and its effects on teachers and students: An interpretive summary of the research. In W. H. Clune \& J. F. Witte (Eds.), Choice and control in American education, Volume 1: The theory of choice and control in education. New York: Falmer Press.

Burawoy, M. (1979) Manufacturing consent: Changes in the labor process under monopoly capitalism. Chicago: University of Chicago Press.

Bureau of National Affairs. (1998). BNAs quarterly report on job absence and turnover. Bulletin to Management. Washington, DC: Bureau of National Affairs.

Burns, T., \& Stalker, G. M. (1961). The management of innovation. London: Tavistock.

Chapman, D., \& Green, M. (1986). Teacher retention: A further examination. The Journal of Educational Research, 79, 273-279.

Chapman, D., \& Hutcheson, S. (1982). Attrition from teaching careers: A discriminant analysis. The American Education Research Journal, 19, 93-105.

Chubb, J. E., \& Moe, T. (1990). Politics, markets and America's schools. Washington, DC: Brookings Institute.

Clinton, W. (1999). State of the union address. Washington DC: U.S. Government Printing Office.

Coleman, J., \& Hoffer, T. (1987). Public and private schools: The impact of communities. New York: Basic.

Darling-Hammond, L. (1984). Beyond the commission reports: The coming crisis in teaching. Santa Monica, CA: Rand Corporation.

Darling-Hammond, L., \& Green, J. (1994). Teacher quality and equality. In P. Keating \& J. I. Goodlad (Eds.), Access to Knowledge. New York: College Entrance Examination Board.

Darling-Hammond, L., \& Hudson, L. (1989). Teachers and teaching. In R. Shavelson, L. McDonnell, \& J. Oakes (Eds.), Indicators for monitoring mathematics and science education (pp. 66-95). Santa Monica, CA: Rand Corporation. 


\section{Ingersoll}

Durkheim, E. (1961). Moral education: A study in the theory and application of the sociology of education (E. K. Wilson, \& H. Schnurer, Trans.). New York: Free Press.

Edwards, R. (1979). Contested terrain. New York: Basic.

Feistritzer, E. (1997). Alternative teacher certification: A state-by-state analysis (1997). Washington, DC: National Center for Education Information.

Gerald, D., \& Hussar, W. (1998). Projections of education statistics to 2008. Washington, DC: National Center for Education Statistics.

Goodlad, J. 1984. A place called school: Prospects for the future. St. Louis: McGraw-Hill.

Grant, G. (1988). The world we created at Hamilton High. Cambridge, MA: Harvard University Press.

Grissmer, D., \& Kirby, S. (1987). Teacher attrition: The uphill climb to staff the nation's schools. Santa Monica, CA: Rand Corporation.

Grissmer, D., \& Kirby, S. (1992). Patterns of attrition among Indiana teachers, 1965-1987. Santa Monica, CA: Rand Corporation.

Grissmer, D., \& Kirby, S. (1997). Teacher turnover and teacher quality. Teachers College Record, 99, 45-56.

Guthrie, J. (1979). Organizational scale and school success. Educational Evaluation and Policy Analysis, 1, 17-27.

Hafner, A., \& Owings, J. (1991). Careers in teaching: Following members of the high school class of 1972 in and out of teaching (NCES Report No. 91-470). Washington, DC: U.S. Department of Education, National Center for Education Statistics.

Haggstrom, G. W., Darling-Hammond, L., \& Grissmer, D. (1988). Assessing teacher supply and demand. Santa Monica, CA: Rand Corporation.

Halaby, C., \& Weakliem, D. (1989). Worker control and attachment to the firm. American Journal of Sociology, 95, 549-591.

Heyns, B. (1988). Educational defectors: A first look at teacher attrition in the NLS-72. Educational Researcher, 17, 24-32.

Hirsch, E., Koppich, J., \& Knapp, M. (2001). Revisiting what states are doing to improve the quality of teaching: An update on patterns and trends. Seattle, WA: Center for the Study of Teaching and Policy, University of Washington.

Hirschman, A. (1970). Exit, voice and loyalty. Cambridge: Harvard University Press.

Hom, P., \& Griffeth, R. (1995). Employee turnover. Cincinnati: South-Western Publishing.

Ingersoll, R. (1993). Loosely coupled organizations revisited. Research in the Sociology of Organizations, 11, 81-112.

Ingersoll, R. (1995a). Teacher supply, teacher qualifications and teacher turnover. Washington, DC: National Center for Education Statistics.

Ingersoll, R. (1995b). An agenda for research on teachers and schools: Revisiting NCES' schools and staffing survey. Washington, DC: National Center for Education Statistics.

Ingersoll, R. (1996). Teachers' decision-making power and school conflict. Sociology of Education, 69, 159-176.

Ingersoll, R. (1997). Teacher professionalization and teacher commitment: A multilevel analysis. Washington, DC: National Center for Education Statistics.

Ingersoll, R. (1999). The problem of underqualified teachers in American secondary schools. Educational Researcher, 28, 26-37.

Ingersoll, R. (2000). Turnover among mathematics and science teachers in the U.S. Washington, DC: National Commission on Mathematics and Science Teaching for the 21st Century. (www.ed.gov/americacounts/glenn/compapers.html/)

Ingersoll, R. (2001a). Teacher turnover, teacher shortages and the organization of schools. Seattle, WA: Center for the Study of Teaching and Policy, University of Washington. 
Ingersoll, R. (2001b). Control, accountability, and America's teachers. Manuscript submitted for publication.

Kalleberg, A., \& Mastekaasa, A. (1998). Organizational size, layoffs and quits in Norway. Social Forces, 76, 1243-73.

Kanter, R. (1977). Men and women of the corporation. New York: Basic.

Kirst, M. (1989). Who should control the schools? In T. J. Sergiovanni \& J. Moore (Eds.), Schooling for tomorrow. Boston: Allyn and Bacon.

Kopp, W. (1992). Reforming schools of education will not be enough. Yale Law and Policy Review, 10, 58-68.

Kozol, J. (1991). Savage inequalities. New York: Harper-Collins.

Likert, R. (1967). The human organization. New York: McGraw-Hill.

Lortie, D. (1975). School teacher. Chicago: University of Chicago Press.

March, J., \& Simon, H. (1958). Organizations. New York: Wiley.

Marso, R., \& Pigge, F. (1991). The impact of student transfers on teacher candidate quality. Education Review, 14, 19-32.

Metz, M. (1986). Different by design. London: Routledge and Kegan Paul.

Miech, R., \& Elder, R. (1996). The service ethic and teaching. Sociology of Education, 69, 237-253.

Mobley, W. (1982). Employee turnover: Causes, consequences and control. Reading, MA: Addison-Wesley.

Mueller, C., \& Price, J. (1990). Economic, psychological and sociological determinants of voluntary turnover. Journal of Behavioral Economics, 19, 321-335.

Murnane, R. (1981). Teacher mobility revisited. Journal of Human Resources, 16(1), 3-19.

Murnane, R. (1987). Understanding teacher attrition. Harvard Educational Review, $57(2), 177-182$.

Murnane, R., Singer, J., \& Willett, J. (1988). The career paths of teachers: Implications for teacher supply and methodological lessons for research. Educational Researcher, 17(5), 22-30.

Murnane, R., Singer, J., Willett. J., Kemple, J., \& Olsen, R. (Eds.). (1991). Who will teach?: Policies that matter. Cambridge, MA: Harvard University Press.

National Academy of Sciences. (1987). Toward understanding teacher supply and demand. Washington, DC: National Academy Press.

National Commission on Excellence in Education. (1983). A nation at risk: The imperative for educational reform. Washington, DC: Government Printing Office.

National Commission on Teaching and America's Future. (1997). Doing what matters most: Investing in quality teaching. New York: NCTAF.

Newman, F., Rutter, R., \& Smith, M. (1989). Organizational factors that affect school sense of efficacy, community and expectations. Sociology of Education, 62, 221-38.

Oakes, J. (1990). Multiplying inequalities: The effects of race, social class, and tracking on opportunities to learn mathematics and science. Santa Monica, CA: The RAND Corporation.

Pallas, A. (1988). School climate in American high schools. Teachers College Record, 89, 541-543.

Parsons, T. 1959. The school class as a social system: Some of its functions in American society. Harvard Educational Review, 29, 297-318.

Porter, L. W., Lawler, E. E., \& Hackman, J. R. (1975). Behavior in organizations. New York: McGraw-Hill.

Price, J. (1977). The study of turnover. Ames, IA: Iowa State University Press.

Price, J. (1989). The impact of turnover on the organization. Work and Occupations, $16,461-473$. 


\section{Ingersoll}

Price, J. (1997). Handbook of organizational measurement. International Journal of Manpower, 18 (4-6)

Reyes, P. (1990). Teachers and their workplace: Commitment, performance, productivity. Newbury Park, CA: Sage.

Rollefson, M., \& Broughman, S. (1995). Teacher supply in the United States: Sources of newly bired teachers in public and private schools, 1988-1991. Washington, DC: National Center for Education Statistics.

Rosenholtz, S. (1985, January). Political myths about education reform: Lessons from research on teaching. Phi Delta Kappan, 66(5), 349-355.

Rosenholtz, S. (1989). Teacher's workplace: The social organization of schools. New York: Longman.

Rowan, B., Raudenbush, S., \& Kang, S. J. (1991). Organizational design in high schools: A multilevel analysis. American Journal of Education, 99, 238-260.

Rumberger, R. (1987). The impact of salary differentials on teacher shortages and turnover: The case of mathematics and science teachers. Economics of Education Review, 6, 389-399.

Schlecty, P., \& Vance, V. (1981). Do academically able teachers leave education? The North Carolina case. Phi Delta Kappan, 63, 105-112.

Schlecty, P., \& Vance, V. (1983). Recruitment, selection and retention: The shape of the teaching force. Elementary School Journal, 83, 469-487.

Sclan, E. (1993). The effect of perceived workplace conditions on beginning teachers work commitment, career choice commitment and planned retention. Ann Arbor, MI: University Microfilms International.

Snyder, T., Hoffman, C., \& Geddes, C. (1997). The Digest of Education. Washington, DC: U.S. Department of Education, National Center for Education Statistics.

Steers, R. M., \& Momday, R. T. (1981). Employee turnover and the post-decision accommodation process. In B. M. Shaw \& L. L. Cummings (Eds.), Research in organizational behavior. Greenwich: JAI Press.

Theobald, N. (1990). An examination of the influence of personal, professional and school district characteristics on public school teacher retention. Economics of Education Review, 9, 241-250.

Turner, A. N., \& Lawrence, P. R. (1964). Industrial jobs and the worker. Cambridge, MA: Harvard University Press.

U.S. Bureau of the Census. (1998). Statistical abstract (117th Edition). Washington, DC: U.S. Department of Commerce.

Walberg, H., \& Walberg, H. (1994). Losing local control. Educational Researcher, 23(5), 19-26.

Waller, W. (1932). The sociology of teaching. New York: Wiley.

Walton, R. E. (1980). Establishing and maintaining high commitment work systems. In J. Kimberly \& R. Miles (Eds.), The organization life cycle. San Francisco: Jossey-Bass.

Weiss, I. R., \& Boyd, S. E. (1990). Where are they now?: A follow-up study of the 1985-86 science and mathematics teaching force. Chapel Hill, NC: Horizon Research, Inc.

William M. Mercer (1999). Survey of registered nurse attraction and retention. Atlanta, GA: William M. Mercer, Inc.

Manuscript received January 10, 2000

Revision received October 30, 2000

Accepted February 6, 2001 